\title{
RESEARCH NOTE \\ Effects of egg shell color and storage duration on the external and internal egg quality traits of ATAK-S layer hybrids
}

\author{
Ahmet Şekeroğlu ${ }^{1}$, Hamdiye Gök ${ }^{2}$, and Mustafa Duman ${ }^{3}$ \\ ${ }^{1}$ Department of Animal Production and Technologies, Faculty of Agricultural Sciences and Technologies, \\ University of Niğde TR-51240 Niğde, Turkey. \\ ${ }^{2}$ Department of Animal Science, Faculty of Agriculture, University of Gaziosmanpaşa, TR-60250 Tokat, \\ Turkey. \\ ${ }^{3}$ Bor Vocational School, University of Niğde, Department of Laboratory and Veterinary Health, TR-51700 \\ Bor, Niğde, Turkey.
}

\begin{abstract}
A. Şekeroğlu, H. Gök, and M. Duman. 2016. Effects of egg shell color and storage duration on the external and internal egg quality traits. Cien. Inv. Agr. 43(2):327-335. The present study was conducted to investigate the effects of storage duration and egg shell color on external and internal egg quality traits. Eggs were obtained from 29-week--old ATAK-S layer hybrids reared in a traditional cage system. Storage durations were set as $0,7,14,21$ and 28 days. Shell color was classified as dark (59.00-67.99); moderate (68.00-70.99) and light (71.00-79.99) using the $\Delta \mathrm{E}$ values of the eggs. The storage duration significantly affected the egg weight ( $P \leq 0.01)$, specific gravity $(P \leq 0.01)$, breaking strength ( $P \leq 0.01)$, shell thickness $(P \leq 0.01)$, shell weight $(P \leq 0.01)$, surface area $(P \leq 0.01)$, albumen index $(P \leq 0.01)$, yolk index $(P \leq 0.01)$, Haugh unit $(\mathrm{P} \leq 0.01)$, yolk color $(\mathrm{P} \leq 0.05)$ and albumen $\mathrm{pH}(\mathrm{P} \leq 0.01)$. The egg shell color significantly affected the specific gravity $(\mathrm{P} \leq 0.01)$, breaking strength $(\mathrm{P} \leq 0.01)$, shell thickness $(\mathrm{P} \leq 0.01)$, shell weight $(\mathrm{P} \leq 0.01)$, albumen $\mathrm{pH}(\mathrm{P} \leq 0.05)$ and albumen blood-meat spots $(\mathrm{P} \leq 0.05)$. The current findings revealed that the eggs should be transported to consumers as soon as possible, and further studies should be performed to darken egg shell colors. It was concluded that newly laid dark colored eggs had the best quality.
\end{abstract}

Key words: ATAK-S, brown egg, hen, poultry, quality characteristics.

\section{Introduction}

In the poultry industry, the developments in genetics, rearing systems, feeding and health conditions have increased the annual egg yield of hens up to 310 eggs per hen. Parallel to increasing egg production, significant improvements were

Received November 26, 2015. Accepted July 18, 2016. Corresponding author: ahmet.sekeroglu@nigde.edu.tr observed in egg quality parameters. Therefore, the factors effecting egg quality, such as herd genotype, age, rearing system, feeding, health, egg classification, storage, transport, processing technology and marketing, should be welldesigned (Abdullah et al., 1993; Atasoy et al., 2001). Together with the improved social and welfare levels, egg quality is also becoming a significant issue for consumers worldwide. Egg 
preference and hedonic consumption value vary from one person to another. All of the factors that influence egg preference and acceptability affect egg quality parameters. Egg shell color is among the factors influencing egg preference by consumers (Hooge, 2007). In addition to brown and white colored eggs, different tones of brown also influence consumer preferences. Biliverdin, zinc chelate and porphyrine pigments excreted from the uterus of the reproductive track colorize the egg shell. The protoporphyrin content is higher in brown eggs, and the egg shell color varies with different brown tones, ranging from dark brown to light brown based on the amount of this pigment (Kennedy and Vevers, 1973). In brown eggs, the shell color also influences the hatchability. Dark color eggs have better hatchability than light color eggs (Şekeroğlu and Duman, 2011).

Among the pigments coloring egg shells, biliverdin has an antioxidant effect, porphyrin and derivatives have photodynamic and antibacterial effects and protoporphyrin has an egg shell breakage resistance and increased thickness effects. The biliverdin content of an egg shell is an indicator of the egg's antioxidant capacity (Ishikawa et al., 2010; Şekeroğlu and Duman, 2011). In commercial laying hen facilities, storage temperatures play a significant role in delivering the eggs to the consumer at peak laying freshness. Following the laying, based on storage temperature and duration, $\mathrm{CO}_{2}$ and weight losses, increased albumen $\mathrm{pH}$ levels, decreased albumen weight and heights are observed in eggs (Yilmaz and Bozkurt, 2008).

The present study was conducted to investigate the effects of egg shell color on consumer prefer- ences and the storage duration on the internal and external egg quality traits of ATAK-S hybrids.

\section{Materials and methods}

\section{Materials}

The eggs were obtained from ATAK-S layer hybrids housed at Poultry Research Unit of Gaziosmanpaşa University Agricultural Faculty Animal Science Department.

The eggs were obtained in a single day from 1800 ATAK-S hybrids for use in the experiments. The hens were 29-weeks-old and reared in a traditional cage system with 7 hens in each case. Eggs were selected by almost equal weight by weighing the eggs with a precise balance ( $\pm 0.01 \mathrm{~g})$. The shell color parameters of $\mathrm{L}^{*} \mathrm{a}^{*}$ $b^{*}$ (CIE-LAB) were measured with a Minolta Chroma Meter (CR-300, Konica Minolta Co. Ltd., Osaka, Japan), (L*: Brightness, a*: Redness, $b^{*}$ : Yellowness). By using L*, a* and $b^{*}$ values, the shell color $(\Delta \mathrm{E})$ was calculated with the formula $\Delta \mathrm{E}=\left(\mathrm{L}^{2}+\mathrm{a}^{2}+\mathrm{b}^{2}\right)^{1 / 2}($ Ingram et al., 2008). Based on the $\Delta \mathrm{E}$ values, the eggs were classified into three groups of dark-, moderate- and light-colored (Table 1). Then, the classified eggs were stored in an incubation chamber at $10{ }^{\circ} \mathrm{C}$ and $60 \%$ to $80 \%$ relative humidity.

In the egg quality analyses at $0,7,14,21$ and $28^{\text {th }}$ days, 30 eggs from the dark-, moderate- and light-colored groups (90 eggs for each storage duration; 450 eggs in total) were broken, and the quality parameters were analyzed.

Table 1. Egg shell color $(\Delta \mathrm{E})$ groups and average egg weights.

\begin{tabular}{|c|c|c|c|c|c|}
\hline$\Delta \mathrm{E}$ color groups & $\begin{array}{c}\text { Average } \\
\Delta \mathrm{E}\end{array}$ & $\begin{array}{c}\text { Average } \\
\mathrm{L}^{*}\end{array}$ & $\begin{array}{c}\text { Average } \\
a^{*}\end{array}$ & $\begin{array}{c}\text { Average } \\
\mathrm{b}^{*}\end{array}$ & $\begin{array}{c}\text { Weight } \\
\text { G }\end{array}$ \\
\hline Dark (59.00-67.99) & 65.94 & 58.84 & 14.10 & 25.90 & 60.06 \\
\hline Moderate (68.00-70.99) & 69.46 & 62.52 & 12.99 & 27.01 & 60.06 \\
\hline Light (71.00-79.99) & 72.45 & 66.19 & 11.74 & 26.69 & 60.13 \\
\hline
\end{tabular}




\section{Methods}

Egg weight, shape index, specific gravity, shell breaking strength, shell thickness, shell weight, egg surface area and shell color were considered the external quality traits. Egg weights were measured with a precise balance $( \pm 0.01 \mathrm{~g})$. Egg length and widths were measured with a digital caliper, and the shape index was calculated as the width-to-length ratio. Common salt solutions were used to measure the specific gravity. Shell breaking strength was measured using a strength measurement device developed by Rauch, and the results were expressed in $\mathrm{kg} \cdot \mathrm{cm}^{-3}$. Following the removal of the shell membranes, the shell thickness was measured over the bumped, medium and pointed sections of the broken shells with a micrometer $( \pm 1 / 100 \mathrm{~mm})$. Then, the average of the three measurements constituted the egg shell thickness. The shell weight was calculated with the following formula, and the egg shell surface area (A) was calculated with the following formula specified by Nordstorm and Ousterhout (1982).

Shell Weight $(\mathrm{g})=((2.0341 \times$ Egg Weight $(\mathrm{g}))-(2.1014$ $\times$ Egg Weight(g)))/ Egg Specific Gravity $\left(\mathrm{g} \mathrm{cm}^{-3}\right)$

\section{$\mathrm{A}=3.9782 \times$ Egg weight $^{0.7056}$}

A specifically designed mirrored glass table was used to measure the eggs' internal quality traits. Albumen index, yolk index, Haugh unit, yolk color, albumen $\mathrm{pH}$, blood and meat spots were considered the internal quality traits. Thick albumen height and yolk height were measured with a tripod micrometer $( \pm 1 / 100 \mathrm{~mm})$. Albumen length, width and yolk diameter were measured with Vernier calipers (Efil and Sarıca, 1997). Albumen and yolk indexes were measured with the following formulas:

Albumen Index $=($ Thick albumen height $(\mathrm{mm}) /$ Average albumen length and width $(\mathrm{mm})) \times 100$

Yolk Index $=($ Yolk height $(\mathrm{mm}) /$ Yolk Diameter $(\mathrm{mm})) \times 100$
Egg weight and albumen height were used to calculate the Haugh units according to the following formula:

Haugh unit $=100 \log \left(\mathrm{H}+7.57-1.7 \mathrm{G}^{0.37}\right)$

where $\mathrm{H}$ is the albumen height ( $\mathrm{mm})$, and $\mathrm{G}$ is the egg weight $(\mathrm{g})$.

A Roche color circle with 15 sections was used to identify the yolk color. Albumen $\mathrm{pH}$ was measured with a pH meter (Sartoriious PP15, AG Weender Landstrasse 94-108, Goettingen, Germany). The ratio of eggs with blood and meat spots was determined using a glass table equipped with an inclined mirror underneath; blood and meat spots were assessed together. Blood-meat spots over the albumen and yolk were separately assessed as either existent - non-existent.

The effects of the egg shell color and storage duration on the internal and external egg quality traits were assessed using analysis of variance (ANOVA) performed with SPSS 17.0. Duncan's multiple range tests were used to compare the means. Because the data pertaining to blood and meat spots were classified as either existent or non-existent, a nonparametric Kruskal-Wallis $\mathrm{H}$ test was used for these data.

\section{Results and discussion}

\section{External egg quality traits}

The effects of the egg shell color and storage duration on the external egg quality traits of egg weight, shape index, specific gravity, breaking strength, shell thickness, shell weight, egg surface area and shell color were investigated (Table 2).

While the effects of storage duration on egg weight, specific gravity, breaking strength, shell thickness, shell weight, shell surface area and shell color were found to be significant $(\mathrm{P} \leq 0.01)$, the effects on the shape index were found to be insignificant $(\mathrm{P}>0.05)$. Egg shell color had a significant effect 
Table 2. Effects of storage duration and egg shell color on external egg quality traits.

\begin{tabular}{|c|c|c|c|c|c|c|c|c|c|}
\hline & & $\begin{array}{c}\text { Egg } \\
\text { Weight }\end{array}$ & $\begin{array}{l}\text { Shape } \\
\text { Index }\end{array}$ & $\begin{array}{l}\text { Specific } \\
\text { Gravity }\end{array}$ & $\begin{array}{l}\text { Breaking } \\
\text { Strength }\end{array}$ & $\begin{array}{c}\text { Shell } \\
\text { Thickness }\end{array}$ & $\begin{array}{c}\text { Shell } \\
\text { Weight }\end{array}$ & $\begin{array}{c}\text { Surface } \\
\text { Area }\end{array}$ & $\begin{array}{c}\text { Shell } \\
\text { Color (E) }\end{array}$ \\
\hline \multicolumn{10}{|c|}{ External egg quality traits } \\
\hline \multirow{5}{*}{ 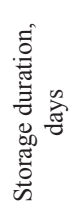 } & Initial & $60.39 \mathrm{c}$ & 77.29 & $1.087 \mathrm{~d}$ & $2.17 \mathrm{a}$ & $33.88 \mathrm{a}$ & $6.14 \mathrm{~d}$ & $71.82 \mathrm{c}$ & $68.68 \mathrm{a}$ \\
\hline & 7 & $59.67 \mathrm{bc}$ & 77.57 & $1.083 \mathrm{c}$ & $2.78 \mathrm{~b}$ & $34.99 \mathrm{~b}$ & $5.59 \mathrm{c}$ & $71.20 \mathrm{bc}$ & $72.23 \mathrm{bc}$ \\
\hline & 14 & $59.24 \mathrm{ab}$ & 77.88 & $1.076 \mathrm{~b}$ & $2.69 \mathrm{~b}$ & $34.99 \mathrm{~b}$ & $4.83 \mathrm{~b}$ & $70.84 \mathrm{ab}$ & $72.38 \mathrm{c}$ \\
\hline & 21 & $59.22 \mathrm{ab}$ & 78.56 & $1.077 \mathrm{~b}$ & $2.63 \mathrm{~b}$ & $35.99 \mathrm{c}$ & $4.97 \mathrm{~b}$ & $70.85 \mathrm{ab}$ & $73.59 \mathrm{~d}$ \\
\hline & 28 & $58.60 \mathrm{a}$ & 77.08 & $1.072 \mathrm{a}$ & $2.64 \mathrm{~b}$ & $34.64 \mathrm{~b}$ & $4.35 \mathrm{a}$ & $70.31 \mathrm{a}$ & $71.69 \mathrm{~b}$ \\
\hline \multirow{3}{*}{ 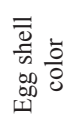 } & Light & 59.56 & 77.89 & $1.078 \mathrm{a}$ & $2.42 \mathrm{a}$ & $34.36 \mathrm{a}$ & $5.11 \mathrm{a}$ & 71.12 & $73.62 \mathrm{c}$ \\
\hline & Moderate & 59.34 & 77.50 & $1.079 \mathrm{~b}$ & $2.53 \mathrm{a}$ & $34.84 \mathrm{a}$ & $5.20 \mathrm{ab}$ & 70.93 & $71.81 \mathrm{~b}$ \\
\hline & Dark & 59.43 & 77.66 & $1.080 \mathrm{~b}$ & $2.79 \mathrm{~b}$ & $35.51 \mathrm{~b}$ & $5.28 \mathrm{~b}$ & 70.82 & $69.66 \mathrm{a}$ \\
\hline \multicolumn{10}{|c|}{ Source of variation $P$ values } \\
\hline \multicolumn{2}{|c|}{ Storage duration } & $* *$ & NS & $* *$ & $* *$ & $* *$ & $* *$ & $* *$ & $* *$ \\
\hline \multicolumn{2}{|c|}{ Egg shell color } & NS & NS & $* *$ & $* *$ & $* *$ & $*$ & NS & $* *$ \\
\hline \multicolumn{2}{|c|}{ Interaction } & NS & NS & $* *$ & NS & NS & NS & NS & $* *$ \\
\hline
\end{tabular}

Within each column, means followed by different letters are significantly different. $\left({ }^{*} \mathrm{P} \leq 0.05 ; * \mathrm{P} \leq 0.01\right)$. NS: Not significant.

on specific gravity $(\mathrm{P} \leq 0.01)$, breaking strength $(P \leq 0.01)$, shell thickness $(P \leq 0.01)$, shell weight $(\mathrm{P} \leq 0.05)$ and shell color $(\mathrm{P} \leq 0.01)$. The effects of the egg shell color on the shape index and egg surface area were not significant $(\mathrm{P}>0.05)$. The interactions between the storage durations and the egg shell color were found to be significant regarding the egg's specific gravity and shell color characteristics $(\mathrm{P} \leq 0.01)$ and insignificant regarding the other external egg quality traits $(\mathrm{P}>0.05)$.

The present findings agree with the findings of Scott and Silversides (2000), Yllmaz and Bozkurt (2008), Oliveira et al. (2009) and Raji et al. (2009), indicating decreasing egg weights with increasing storage durations. However, despite the decreasing egg weights, there are various other researchers reporting insignificant effects of storage durations on egg weights (Şaml et al., 2005; Şekeroğlu et al., 2008; Akyürek and Okur, 2009; Alsobayel and Albadry, 2011; Okur and Şaml1, 2013), and the current findings agree with the findings of Demirel and Kırıkçı (2009), indicating that the duration of storage did not have any effect on egg weight.

The present findings agree with the results of previous researchers, indicating insignificant impacts of the storage duration on the shape index (Y1lmaz and Bozkurt, 2008; Akyürek and Okur, 2009; Demirel and Kırıkçı, 2009; Raji et al., 2009; Alsobayel and Albadry, 2011).

The findings of egg specific gravity, which is closely related to the egg shell quality, are similar to results reported by Şamlı et al. (2005), Şekeroğlu et al. (2008), Akyürek and Okur (2009), and Alsobayel and Albadry (2011). Higher breaking strength values at the end of the storage period than the initial values agree with the findings of Yilmaz and Bozkurt (2008).

Y1lmaz and Bozkurt (2008) and Demirel and Kırıkçı (2009) investigated the effects of storage durations on egg shell quality and reported similar results with the present study and indicated increasing shell thicknesses with increasing storage durations. Alsobayel and Albadry (2011) reported significant effects of storage durations on shell thickness and, contrary to previous studies, reported decreasing shell thicknesses with increasing storage durations. In contrast, some researchers reported that the storage duration did not have any significant impacts on shell thickness (Şamlı et al., 2005; Okur and Şaml1, 2013; Englmaierová and Tůmová, 2009). 
The current findings were similar to findings of Şamlı et al. (2005), Jin et al. (2011), Englmaierová and Tůmová (2009), and Okur and Şamlı (2013), indicating that there was an effect of storage duration on shell weight.

Decreasing egg surface areas were observed with increasing storage durations. These findings were similar to results of Scott and Silversides (2000), Englmaierová and Tůmová (2009), Oliveira et al. (2009), and Raji et al. (2009).

The current findings were found to be similar with the results of Shafey et al. (2005) and Kożuszek et al. (2009), indicating unchanged egg weights with darkening shell colors; however, this was not concurrent with the findings of Aygun (2014) who reported increasing egg weights with darkening shell colors.

Kożuszek et al. (2009) reported increasing shape index values with darkening shell colors. The inconsistency in the literature was because hen eggs were used in this study but pheasant eggs were used in Kożuszek et al. (2009).

Increasing specific gravity values were observed with darkening shell colors. These findings comply with the results of Kożuszek et al. (2009); however, Ingram et al. (2008) reported decreasing specific gravity values with darkening shell colors.

Increasing breaking strength values were observed with darkening shell colors. Similar to this study, Aygun (2014) reported increasing breaking strength values with darkening shell colors.

Increasing shell thickness was observed in this study with darkening shell colors. The present findings comply with the results of Ingram et al. (2008), Kożuszek et al. (2009), and Şekeroğlu and Duman (2011), indicating increasing shell thicknesses with darkening shell colors.

Increasing shell weights were observed with darkening shell colors of the present study. The eggs with dark shell colors had the highest shell weights. However, Shafey et al. (2005) and Kożuszek et al. (2009) indicated that shell color did not have a significant effects on shell weight.

Despite the insignificant differences the egg surface areas of different color tones, decreasing surface areas were observed with darkening shell colors. Kożuszek et al. (2009) also reported similar findings to this study.

\section{Internal egg quality traits}

The effects of egg shell color and storage duration on internal egg quality traits are provided in Table 3. While the effect of storage duration on albumen index $(\mathrm{P} \leq 0.01)$, yolk index $(\mathrm{P} \leq 0.01)$, Haugh unit $(\mathrm{P} \leq 0.01)$, albumen $\mathrm{pH}(\mathrm{P} \leq 0.01)$ and yolk color $(\mathrm{P} \leq 0.05)$ were found to be significant. The effects of egg shell color and storage duration on the blood-meat spot ratio of albumen and yolk were not found to be significant. While the effect of egg shell color on albumen $\mathrm{pH}$ and the albumen blood-meat ratio were found to be significant $(\mathrm{P} \leq 0.05)$, effects on the other internal egg quality traits were not found to be significant $(\mathrm{P}>0.05)$.

Effects of storage duration on albumen index were found to be significant, and decreasing index values were observed with increasing storage durations. Current findings were similar to results of Şekeroğlu et al. (2008), Yılmaz and Bozkurt (2008), Akyürek and Okur (2009), Demirel and Kırıkçı (2009), Khan et al. (2013) and Raji et al. (2009).

Decreasing yolk index values were observed with increasing storage durations. Şamlı et al. (2005) also reported similar findings to the current study.

Haugh units decreased with increasing storage durations of the present study. Jones and Musgrove (2005), Şamlı et al. (2005), Şekeroğlu et al. (2008), Yılmaz and Bozkurt (2008), Akyürek and Okur (2009), Demirel and Kırıkçı (2009), Raji et al. (2011), 
Table 3. Effects of storage duration and egg shell color on internal egg quality traits.

\begin{tabular}{|c|c|c|c|c|c|c|c|c|}
\hline & & $\begin{array}{l}\text { Albumen } \\
\text { Index }\end{array}$ & $\begin{array}{l}\text { Yolk } \\
\text { Index }\end{array}$ & Haugh Unit & $\begin{array}{l}\text { Yolk } \\
\text { Color }\end{array}$ & $\begin{array}{c}\text { Albumen } \\
\mathrm{pH}\end{array}$ & $\begin{array}{l}\text { Albumen } \\
\text { Blood- } \\
\text { Meat Spots }\end{array}$ & $\begin{array}{c}\text { Yolk } \\
\text { Blood- } \\
\text { Meat Spots }\end{array}$ \\
\hline \multicolumn{9}{|c|}{ Internal egg quality traits } \\
\hline \multirow{5}{*}{ 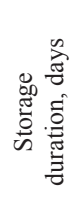 } & Initial & $11.63 \mathrm{e}$ & $44.47 \mathrm{~d}$ & $94.56 \mathrm{~d}$ & $11.29 \mathrm{~b}$ & $8.62 \mathrm{a}$ & 0.08 & 0.14 \\
\hline & 7 & $9.68 \mathrm{~d}$ & $43.73 \mathrm{~cd}$ & $87.64 \mathrm{c}$ & $10.96 \mathrm{a}$ & $9.15 \mathrm{~b}$ & 0.04 & 0.12 \\
\hline & 14 & $8.79 \mathrm{c}$ & $43.07 \mathrm{c}$ & $84.41 \mathrm{~b}$ & $10.98 \mathrm{a}$ & $9.11 \mathrm{c}$ & 0.10 & 0.08 \\
\hline & 21 & $8.16 \mathrm{~b}$ & $41.26 \mathrm{~b}$ & $82.89 \mathrm{~b}$ & $11.04 \mathrm{a}$ & $9.28 \mathrm{~d}$ & 0.10 & 0.04 \\
\hline & 28 & $7.13 \mathrm{a}$ & $40.26 \mathrm{a}$ & $78.47 \mathrm{a}$ & $11.09 \mathrm{a}$ & $9.28 \mathrm{~d}$ & 0.06 & 0.12 \\
\hline \multirow{3}{*}{ 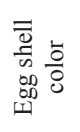 } & Light & 9.11 & 42.57 & 85.93 & 10.99 & $9.09 \mathrm{~b}$ & $0.04 \mathrm{a}$ & 0.06 \\
\hline & Moderate & 9.07 & 42.63 & 85.48 & 11.09 & $9.09 \mathrm{~b}$ & $0.06 \mathrm{a}$ & 0.14 \\
\hline & Dark & 9.19 & 42.65 & 85.89 & 11.13 & $9.06 \mathrm{a}$ & $0.12 \mathrm{~b}$ & 0.10 \\
\hline \multicolumn{2}{|c|}{ Storage duration } & $* *$ & $* *$ & $* *$ & $*$ & $* *$ & NS & NS \\
\hline \multicolumn{2}{|c|}{ Egg shell color } & NS & NS & NS & NS & $*$ & $*$ & NS \\
\hline \multicolumn{2}{|c|}{ Interaction } & NS & NS & NS & NS & NS & NS & NS \\
\hline
\end{tabular}

Within each column, means followed by different letters are significantly different. ( $\left.{ }^{*} \mathrm{P} \leq 0.05 ; * \mathrm{P} \leq 0.01\right)$. NS: Not significant.

Alsobayel and Albadry (2011), Khan et al. (2013), and Okur and Şamlı (2013) carried out experiments on internal egg quality traits and reported similar findings with the present study. Contrary to those studies, Jin et al. (2011) reported insignificant effects of storage durations on the Haugh unit.

Yolk colors decreased with increasing storage durations. These findings comply with the results of Yilmaz and Bozkurt (2008), Akyürek and Okur (2009) and Jin et al. (2011). However, Şekeroğlu et al. (2008) reported increasing yolk colors with increasing storage durations. On the other hand, Alsobayel and Albadry (2011) indicated an insignificant effect of storage duration on yolk color.

The effect of storage duration on the albumen $\mathrm{pH}$ values was found to be significant in this study, and increasing $\mathrm{pH}$ values were observed with increasing storage durations. Şamlı et al. (2005), Şekeroğlu et al. (2008), Akyürek and Okur (2009) and Jin et al. (2011) carried out similar studies and reported significant effects of storage durations on albumen $\mathrm{pH}$ and observed increasing $\mathrm{pH}$ values with increasing storage durations. Okur and Şamlı (2013) also reported significant effects of storage durations on albumen $\mathrm{pH}$ values, but they reported decreasing $\mathrm{pH}$ values with increasing storage durations.
In the present study, the effect of the storage duration on the albumen blood-meat spot ratios was found to be insignificant. Alsobayel and Albadry (2011) also reported an insignificant effect of the storage duration on meat spots but a significant effect on blood spots.

The effect of the storage duration on the yolk blood-meat spot ratio was also found to be insignificant. Similarly, Alsobayel and Albadry (2011) reported an insignificant effect of the storage duration on yolk meat spots but it significantly affected blood spots.

Despite the numerical increases in the yolk index values, albumen index and yolk index, the different color tones were not significantly different.

The effect of the egg shell color on the Haugh unit was not found to be significant. However, Aygun (2014) reported decreasing Haugh units and Kożuszek et al. (2009) reported increasing Haugh units with darkening shell colors.

Although shell color did not have any significant effects on yolk color, increasing yolk color values were observed with darkening shell colors. Aygun 
(2014) reported that egg shell color did not have any significant effects on egg yolk color.

The effect of egg shell color on albumen $\mathrm{pH}$ was found to be significant, and decreasing $\mathrm{pH}$ values were observed with darkening shell colors. However, Kożuszek et al. (2009) reported increasing albumen $\mathrm{pH}$ values with darkening shell colors.

Effects of the egg shell color on albumen bloodmeat spots were found to be significant in this study, and an increasing number of blood-meat spots were observed with darkening shell colors. The egg shell color did not have a significant effect on the yolk blood-meat spots.

Egg quality is the most significant factor affecting the consumer preferences. There are several preand post-laying factors effecting egg quality. A newly laid egg has the highest quality; however, each day until the delivery of the egg to the consumers results in decreases in egg quality traits. The present study was conducted to investigate the effects of storage duration and egg shell color on the external and internal egg quality traits.

Considering the current results, it can be stated that the storage duration negatively impacts egg quality. Decreasing egg weights with increasing storage durations result in economic loss. Additionally, the decrease in external quality traits, such as specific gravity, and internal egg quality traits, such as albumen index, yolk index, Haugh unit and increasing albumen $\mathrm{pH}$ levels, indicated continuously decreasing quality with increasing storage duration. Thus, eggs should be delivered to the consumer as soon as possible after laying.

The effect of the egg shell colors on the egg quality traits was observed in this study. Increasing specific gravity, breaking strength and shell thickness and decreasing albumen $\mathrm{pH}$ levels with darkening shell colors were considered significant changes with regard to egg quality. However, increasing albumen blood-meat spots with darkening shell colors were considered a negative consequence in regard to egg quality. In addition, the shell color did not have negative effect on the other quality traits. Excluding blood-meat spots, darkening shell color either had a positive effect or did not have a significant effect on the other quality traits. Thus, further studies are recommended to darken the brown shell color of laying hens. Finally, it was concluded that newly laid dark color eggs had the highest quality.

\section{Acknowledgements}

This project (Project no: 2009/65) was supported by the Gaziosmanpaşa University Scientific Research Projects Department in Turkey.

\title{
Resumen
}

\begin{abstract}
A. Şekeroğlu, H. Gök y M. Duman. 2016. Efecto del color de la cáscara del huevo y el tiempo de conservación sobre las características de cualidad externas e internas del huevo. Cien. Inv. Agr. 43(2):327-335. El presente estudio evaluó los efectos del tiempo de conservación y el color de la cáscara del huevo en las características de calidad externas e internas del huevo. El material lo constituyeron huevos obtenidos de ATAK-S híbridos de gallinas de postura de 29 semanas de edad, criadas en sistemas de jaula tradicional. El tiempo de duración fue definido como inicial (0), 7, 14, 21 y 28 días. El color de la cáscara fue clasificado como oscuro (59.00-67.99); moderado (68.00-70.99) y claro (71.00-79.99), usando el $\Delta \mathrm{E}$ valores de huevos. El tiempo de conservación tuvo un afecto significativo en el peso del huevo ( $\mathrm{P} \leq 0.01)$, la gravedad específica $(\mathrm{P} \leq 0.01)$, la resistencia a la ruptura $(\mathrm{P} \leq 0.01)$, el grosor de la cáscara $(\mathrm{P} \leq 0.01)$, el peso de la cáscara $(\mathrm{P} \leq 0.01)$, el área de superficie $(\mathrm{P} \leq 0.01)$, el índice de albumen $(\mathrm{P} \leq 0.01)$, el índice de yema $(\mathrm{P} \leq 0.01)$, la unidad Haugh $(\mathrm{P} \leq 0.01)$, el color
\end{abstract}


de la yema $(\mathrm{P} \leq 0.05)$ y el $\mathrm{pH}$ del albumen $(\mathrm{P} \leq 0.01)$. El color de la cáscara originó un efecto significativo en la gravedad específica $(\mathrm{P} \leq 0.01)$, la resistencia a la ruptura $(\mathrm{P} \leq 0.01)$, el grosor de la cáscara ( $\mathrm{P} \leq 0.01)$, el peso de la cáscara $(\mathrm{P} \leq 0.01)$, el pH del albumen $(\mathrm{P} \leq 0.05)$, manchas de sangre y de carne en el albumen $(\mathrm{P} \leq 0.05)$. Los resultados indican que los huevos deberían ser transportados a los consumidores en forma rápida. Se sugiere realizar estudios adicionales para oscurecer la cáscara de los huevos, ya que se concluye que los huevos ligeramente oscurecidos tienen la mayor calidad.

Palabras clave: ATAK-S, aves de postura, huevos marrón, características de calidad, gallinas.

\section{References}

Abdullah, A.G., R.H. Harms, and O. El-Husseyin. 1993. Various methods of measuring shell quality in relation to percentage of crecked eggs. Poultry Science 72: 2038-2043.

Akyürek, H., and A.A. Okur. 2009. Effect of storage time, temprature and hen age on egg quality in free range layers hens. Journal of Animal and Veterinary Advances 8: 1953-1958.

Alsobayel, A.A., and M.A. Albadry. 2011. Effect of storage period and strain of layer on internal and external quality characteristics of eggs marketed in Riyadh area. Journal of the Saudi Society of Agricultural Sciences 10: 41-45.

Atasoy, F., E.E. Onbaşılar, and S. Apaydın. 2001. Denizli ve ticari tavuk sürülerinde yumurta kalite özelliklerinin karşılaştırılması. Lalahan Hayvancılık Araştırma Enstitüsü Dergisi 41: 89-100.

Aygun, A. 2014. The relationship between eggshell colour and egg quality traits in table eggs. Indian Journal of Animal Research 48: 290-294.

Demirel, Ş., and K. Kırıkçı. 2009. Effect of different egg storage times on some egg quality characteristics and hatchability of pheasants (Phasianus colchicus). Poultry Science 88: 440-444.

Efil, H., and M. Sarıca. 1997. Yumurta tanımında güçlükler ve son gelişmeler. On Dokuz Mayıs Üniversitesi Ziraat Fakültesi Dergisi 12: 141150.

Englmaierová, M., and E. Tůmová. 2009. The effect of housing system and storage time on egg quality characteristics. World Poultry Science Association, Proceedings of the 19th European Symposium on Quality of Poultry Meat, 13th Euro- pean Symposium on the Quality of Eggs and Egg Products, Turku, Finland, 21-25 June, p. 1-7.

Hooge, D.M. 2007. Bacillus subtilis spores improve Brown egg colour. World Poultry 23: $14-15$. Ingram, D.R., L.F. Hatten, and K.D. Homan. 2008. A study on the relationship between eggshell color and egg shell quality in commercial broiler breeders. International Journal of Poultry Science 7: 700 -703.

Ishikawa S., K. Suzuki, E. Fukuda, K. Arihara, Y. Yamamoto, T. Mukai, and M. Itoh. 2010. Photodynamic antimicrobial activity of avian eggshell pigments. FEBS Letters 584: 770-774.

Jin, Y.H., K.T. Lee, W.I. Lee, and Y.K. Han. 2011. Effects of storage temperature and time on the quality of eggs from laying hens at peak production. Asian-Australasian Journal of Animal Sciences 24: $279-284$.

Jones, D.R., and M.T. Musgrove. 2005. Effects of extended storage on egg quality factors. Poultry Science 84: 1774-1777.

Kennedy, G.Y., and H.G. Vevers. 1973. Eggshell pigments of the aracuano fowl. Comparative Biochemistry and Physiology - Part B: Biochemistry \& Molecular Biology 44: 11-35.

Khan, M.J.A., S.H. Khan, A. Bukhsh, M.I. Abbass, and M. Javed. 2013. Effect of different storage period on egg weight, internal egg quality and hatchability characteristics of Fayumi eggs. Italian Journal of Animal Science 12: 323-328.

Kożuszek, R., H. Kontecka, S. Nowaczewski, G. Leśnierowski, J. Kijowski, and A. Rosiñsk1. 2009. Quality of pheasant (Phasianus colchicus L.) eggs with different shell colour. European Poultry Science 73: 201-207. 
Nordstorm, J.D., and I.E. Ousterhout. 1982. Estimation of shell weight ana thickness from egg specific gravity ana egg weight. Poultry Science 61: 1991-1995.

Okur, A.A., and H.E. Şaml1. 2013. Effects of storage time and temperature on egg quality parameters and electrical conductivities of eggs. Journal of Tekirdag Agricultural Faculty 10: 78-82.

Oliveira, G.E., T.C. Figueiredo, M.R. Souza, A.L. Oliveira, S.V. Cancado, and M.B.A. Gloria. 2009. Bioactive amines and quality of egg from Dekalb hens under different storage conditions. Poultry Science 88:2428-34.

Raji A.O., J. Aliyu, J.U. Igwebuike, and S. Chiroma. 2009. Effect of storage methods and time on egg quality traits of laying hens in a hot dry climate. ARPN Journal of Agricultural and Biological Science 4:1-7.

Scott, T.A., and F.G. Silversides. 2000. The effect of storage and strain of hen on egg quality. Poultry Science 79: 1725-1729.

Shafey, T.M., H.A. Al-Batshan, and M. S., Al-Ayed. 2005. Effect of intensty of egg shell pigment and illuminated incubation on hatchability of Brown eggs. British Poultry Science 46: 190-198.

Şamlı, H.E., A. Agma, and N. Şenköylü. 2005. Effects of storage time and temperature on egg quality in old Laying Hens. The Journal of Applied Poultry Research 14: 548-553.

Şekeroğlu, A., M. Sarica, E. Demir, Z. Ulutaş, M. Tilki, and M. Saatç1. 2008. The effects of housing system and storage length on the quality of eggs produced by two lines of laying hens. European Poultry Science 72: 106-109.

Şekeroğlu, A. and M. Duman. 2011. Effect of Egg Shell Colour of Broiler Parent Stocks on Hatching Results, Chickens Performance, Carcass Characteristics, Internal Organ Weights and Some Stress Indicators. Journal of the Faculty of Veterinary Medicine, Kafkas University 17: 837-842.

Yılmaz, A.A. and Bozkurt, Z. 2008. Ana yaş1, depolama süresi ve streç filmle paketlemenin sofralık yumurtaların iç ve dış kalite özelliklerine etkisi. Lalahan Hayvancılık Araştırma Enstitüsü Dergisi 48: 81-91. 
